IdeAs

Idées d'Amériques

$6 \mid 2015$

Migrer dans les Amériques

\title{
The Canadian general election of 2015: The Liberal victory marks a swing back to the center in Canadian politics
}

Andrew Ives

\section{OpenEdition}

Journals

Édition électronique

URL : https://journals.openedition.org/ideas/1253

DOI : $10.4000 /$ ideas. 1253

ISSN : 1950-5701

Éditeur

Institut des Amériques

Référence électronique

Andrew Ives, "The Canadian general election of 2015: The Liberal victory marks a swing back to the center in Canadian politics », IdeAs [En ligne], 6 | 2015, mis en ligne le 16 décembre 2015, consulté le 18 octobre 2022. URL : http://journals.openedition.org/ideas/1253 ; DOI : https://doi.org/10.4000/ ideas. 1253

Ce document a été généré automatiquement le 18 octobre 2022.

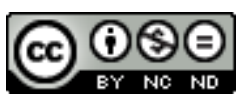

Creative Commons - Attribution - Pas d'Utilisation Commerciale - Pas de Modification 4.0 International - CC BY-NC-ND 4.0

https://creativecommons.org/licenses/by-nc-nd/4.0/ 


\title{
The Canadian general election of 2015: The Liberal victory marks a swing back to the center in Canadian politics
}

\author{
Andrew Ives
}

\section{Introduction}

1 Canadians went to the polls on October $19^{\text {th }} 2015$ and placed the Liberal Party leader, Justin Trudeau, son of former Prime Minister Pierre Elliot Trudeau, at the head of their next government, thereby putting an end to nine years of Conservative Party rule. The left of center New Democratic Party, which had won the second most seats in 2011, had consistently placed first in the early polls that were all predicting a tight three-way race. As the Liberals gained momentum, the NDP started to slide; in the end they finished a distant third, victims of strategic voting in an election year that saw many Canadians motivated primarily by the perspective of voting the Conservatives out of office. The victory of the Liberal Party can be seen as the return of the "natural governing party" in Canada, and to what extent Harper's nine years at the helm have changed Canada will be one of the principal questions raised in the aftermath of the election. Another issue raised in 2015 concerns to what extent demographic trends played a role in the results, notably in accentuating the regional nature of Canadian politics. The 2015 election campaign and electoral results also clearly illustrate a series of problems associated with the first past the post electoral system. The pros and cons of different electoral systems have been discussed by specialists for decades, but 2015 marks the first time the electoral system was invoked in Canadian public debate during a campaign. All major parties except the Conservative Party had promised to reform the electoral system before the next general election. The Liberals will thus be under 
pressure to honour their platform promise to ensure that " 2015 will be the last federal election conducted under the first-past-the-post voting system."

\section{The 2015 election and Canadian political culture}

2 One of the principal objectives of Stephen Harper and his leading advisors during the Conservatives' time in office was to orchestrate an ideological revolution and to durably modify Canadian political culture (Smith, 2012; Patten, 2008). Achieving this objective was tenuous between 2006 and 2011 due to the Conservatives' fragile minority government status, but they held a solid majority from 2011 to 2015, which gave them more latitude to implement their program. As was the case in the USA under the Republican Party, Harper created an alliance between social conservatives and fiscal conservatives in order to create a wide electoral coalition. The main difficulty faced by Harper was that the set of policies to which he was opposed - an advanced welfare state with well-established regulatory agencies, a strong public sector, relatively strong unions, a national policy of multiculturalism, and a foreign policy in which Canada projected itself as a moderate middle power associated with peacekeeping and strong support for the United Nations - were not only the policies of his political adversaries, but, over the years of Liberal Party dominance, they had become part and parcel of the Canadian identity. In trying to sell his neoliberal agenda, he thus found himself battling not only against his political opponents, but also against an entrenched political culture. This state of affairs was due to the central role played by the Liberal Party in governing the nation for much of the $20^{\text {th }}$ century. The Liberals have been the dominant party in Canada since 1896, when Wilfred Laurier became the first native French-speaking prime minister in the young nation's history. Apart from occasional but regular periods of changeover (the Liberals were lucky enough to have the Great Depression coincide with one of the periods of Conservative Party rule), Laurier's reign was followed by other Liberals, some of whom became emblematic long-serving Prime Ministers, notably William Lyon Mackenzie King, Pierre Trudeau and Jean Chrétien (the other Liberal PMs who established policy after Laurier were Louis St Laurent, Lester Pearson and Paul Martin). The result of dominating political life for so long was that many of the policy initiatives that came to define the Canadian nation were enacted by Liberal governments. There has been such a long-standing association between Liberal Party policy and Canadian values, that this year in a reported incident, one of the officials charged with organizing an advanced poll asked for the Canadian flag to be taken down, arguing that electors might presume that it was an advertisement for the Liberal Party. To be fair to the official, he was certainly commenting on the similarity between the national red flag and the prominent red colours used in Liberal Party posters and signs, but a subliminal message may well exist that would associate a vote for the Liberals with a vote for "Team Canada". Harper steadfastly worked to disassociate Keynesian-inspired economic policy from being considered as a Canadian norm; similarly he tried to portray his strong social conservatism as being grounded in an older Canadian tradition. Time will tell to what extent Harper was successful in changing Canadian attitudes.

3 These conflicting views of who best represented Canadians in 2015 played themselves out clearly in the campaign. Harper found himself the target of campaigns in social media in which he was depicted as a threat to Canadian values. In spite of nine years of 
intensive effort to bring Canada closer to his brand of conservatism, his policy initiatives were still seen by many as "un-Canadian" and reminded many people of politics south of the border. During the campaign, he responded by accentuating the split, and thereby setting himself apart from all other parties. Harper tried to link into latent fears in a changing world. As such he axed his campaign on fear: fear of allowing the young inexperienced Trudeau to provoke another recession, fear of how an inexperienced leader would react when confronted with difficult decisions, and, more generally, fear of a dangerous world in which traditional family values were presented as being under threat. The strategy might have worked if Harper's strategists had not pushed a little too far; in the final analysis Conservative Party ads and propaganda were too often judged as inappropriate or in bad taste and they pushed alienated Canadian moderates into the Liberal camp. The aggressive Conservative campaign may also have been one of the factors that motivated younger Canadians to vote, producing the highest voter turnout since 1993. The 2015 campaign thus reveals that the characterization of Canada as a "kinder, gentler nation" still rings true.

\section{Demographic shifts}

The Liberals dominated throughout the $20^{\text {th }}$ century largely due to their solid bastion in Quebec, where people tended to vote as a bloc. The Conservatives under Harper, on the other hand, structured their victories on a stronghold in the West. The two strategies reveal profound demographic changes in Canada that were made most visible in the redistribution of seats that came into effect for the 2015 election. Under the new plan, Alberta and British Columbia each gained six seats, while Saskatchewan and Manitoba remained unchanged; this brought the western total to 104, which represents more than $30 \%$ of the 338 House of Commons seats. Due to rapid demographic growth, the West has moved well beyond the 78 seats granted to Québec (23\% of the total seats). Ontario continues to provide the main ballast with a total of 121 seats, but the central province's domination is slowly slipping away. What's more, in the wake of the North American Free Trade Agreement concluded in 1993, and under Harper's management since 2006, the Canadian economy has become increasingly resource-based. These trends have hurt the old industrial heartland in Ontario and Québec and further increased the political weight of the West. The rising importance of the West both demographically and economically has certainly been of critical importance in a general movement towards the right of the political spectrum for the Canadian electorate. Nationally this has been further enhanced by another major demographic trend, namely the ageing population. Seniors are a key element of the Conservative Party coalition, and this group of electors holds the significant advantage of actually getting out to vote in a country where voter participation is in long term decline (falling from $75 \%$ in the 1980 s to roughly $60 \%$ in the two recent elections of 2008 et 2011). These factors help to explain the increasingly conservative nature of Canadian politics and the three electoral successes of Harper prior to his 2015 defeat. They also give cause for caution before too hastily concluding that the Liberal success in 2015 signals the beginning of another long wave of Liberal Party domination. 


\section{Illustrating the Need for Electoral Reform}

5 While the 2015 election raises a series of interesting questions about the evolution of the Canadian nation in terms of demography, economic policy and political culture, this election may well be remembered as the one that pushed the country firmly in the direction of electoral reform. Already in 2011, the Conservatives had obtained a strong majority with only $39.6 \%$ of the votes. The actual number of Conservative supporters was significantly less than even these figures illustrate: one key advantage held by the Conservative Party has been their popularity among seniors, which has also meant that their electors are more likely to vote. This was a key factor in 2011, when Canada witnessed a record low turnout of only $58.5 \%$ of eligible voters. This inspired a citizens' initiative in 2015 called "Vote together," in which television advertising and social networks were used to inform people, riding by riding, which of the candidates had the best chance to defeat the local Conservative candidate. While strategic voting is a wellknown feature of First Past the Post electoral systems, the 2015 election was unprecedented in its impact. This was due to the fact it was the first election in Canadian history in which there was a competitive three-way race. As such, early polls revealed a very real risk that one of the parties could win a majority in Parliament with only a third of the votes. The danger was accentuated by Conservative Party strategy that seemed to be trying to exploit the flaw in the system by finding wedge issues that would place them in opposition to the two other main parties, thus splitting the opposition vote and winning close seats with limited support. While the strategy did not work in the end - largely due to the Liberals' growing support which made them the obvious choice for strategic voting - electoral results in 2015 reveal the potential of the strategy. In Quebec, for example, where there was a four way race due to the presence of the Bloc Québécois in addition to the three other large parties, the Conservatives took twelve seats, but six of their victories were obtained with less than a third of the votes (the most extreme example was in Rivière du Loup where only $28.5 \%$ of the votes were enough to win the seat). In Saskatchewan's urban ridings, the Conservatives managed to win although their support was significantly less than the total of the NDP and Liberal candidates taken together, while in British Columbia, splitting the votes of their competitors allowed them to hang on to four seats with less than $40 \%$ of the votes cast in those constituencies.

6 Since being granted the status of Dominion in 1867 only two parties have alternated in power federally. The NDP, which has managed to impose itself as a long-standing party, has never managed to form the federal government. In 2011, the party made a significant breakthrough and for the first time became the official Opposition party. But once again in 2015 the party's hopes were dashed by a wave of strategic voting. The Green Party, too, has complained bitterly about an electoral system in which its numerous supporters are left without a voice in parliament (in 2015, 606,000 Green Party votes allowed the election of only one MP). The 2015 election, however, may well be the last one to be contested under the existing rules. The Liberal Party platform included policy resolution $\mathrm{N}^{\circ} 31$, which promised to explore all options for electoral reform. While cynics might suggest that the promise will be soon forgotten, it could be advantageous for the Liberal Party to support a ranked choice voting system: as the party in the middle of the political spectrum, with the Conservatives on their right and the New Democrats on their left, the Liberals would likely garner more second choice 
ballots than their principal political adversaries, thereby allowing them to win more of the closely contested seats in future elections.

\section{Conclusion}

7 The 2015 Canadian election saw Canadians mark a clear break with the Conservative Party after nine years with Stephen Harper as Prime Minister. The victory of Justin Trudeau's Liberals can be seen on one level as a return to power of the "natural governing party." However, the election can also be analyzed as the product of the First Past the Post electoral system: strategic voting was the main consideration for many Canadians who simply wanted to vote the Conservatives out of office, rather than mark their desire for a return to the years of Liberal Party hegemony. This was the first general election to be contested under a new law that fixes the date of federal elections as "the third Monday in October, every four years;" the legislation produced a more American-style campaign in which questions of fundraising and election spending were front and center. Combined with the efforts of the Conservatives over their terms in office to move Canada more in line with American political culture, a creeping form of Americanization seems to be another of the messages hidden in the electoral analysis of 2015.

\section{BIBLIOGRAPHIE}

Patten, Steve, "Understanding Stephen Harper: The long view" in Teresa Healy (dir.) The Harper record, Ottawa, Canadian Center for Policy Alternatives, 2008, p. 25-38.

Smith, Jordan Michael, “Reinventing Canada: Stephen Harper's Conservative Revolution” World Affairs, 28 February 2012, http://worldaffairsjournal.org/article/reinventing-canada-stephenharper\%E2\%80\%99s-conservative-revolution, page consultee le 2 novembre 2015.

\section{AUTEUR}

\section{ANDREW IVES}

Andrew Ives is Associate Professor in North American Studies at the University of Caen, Normandy. Active member of the Association of Canadian Studies in France (AFEC), he has published widely in the fields of political history, political science and the history of ideas. andrew.ives@unicaen.fr 